\title{
THE LITHUANIAN METRICA
}

\section{ARTÜRAS DUBONIS}

The Lithuanian Metrica is the name given to the registers of documents which were sent or received by the chancery of the Grand Duchy of Lithuania. These books are replete with grandducal charters for state territories (lands, duchies and so forth), private individuals, towns and social groups. The Metrica books also contain various acts and documents from grand-ducal and other courts (including the Vilnius Castle Court records), diplomatic material (involving countries ranging from Sweden to the Ottoman Empire, the Holy See to Russia and the Tatar Hordes), financial records, grand-ducal and noble property inventories, chancery handbooks and so on. Over the centuries the Metrica formed the most important archive of the Grand Duchy of Lithuania. The oldest documents date back to 1385-1387 and deal with the beginning of political strategic union with the Kingdom of Poland and the conversion of Lithuania. The latest come from the end of the eighteenth century when rapacious neighbours, Austria, Prussia and Russia, partitioned the Polish-Lithuanian Commonwealth (17721795). The Metrica serve as the broadest and most detailed source available for the early modern history of what are now the republics of Lithuania and Belarus and in a narrower sense, that of Ukraine and Poland too. It also contains many data that illustrate the history of Russia, Prussia, Latvia and Estonia.

The first Metrica books appeared during the reign of Grand Duke Casimir Jagiellończyk (1440-1492). Before that during Vytautas' reign (1392-1430) there were no fixed rules in the Lithuanian chancery for making copies of all documents issued or received by the grand dukes and it would be from booklets of such copies later that the chancery registers we know as the Metrica would be made. ${ }^{1}$

1 A. Dubonis, 'Raštininkas', Lietuvos Didžiosios Kunigaikštijos kultūra: tyrinejimai ir vaizdai (Vilnius, 2001), p. 576. 
Nevertheless, there are hints that documents received by the grand dukes may have been copied into registers in the early $1430 \mathrm{~s}^{2}$ The first peciae or brochures of copies of the grand dukes' in-coming and out-going documents, called 'the chancery books of the Grand Duchy of Lithuania' date back to around 1480-1486. The oldest comprise foreign policy documents. ${ }^{3}$ At the same time volumes of grand-ducal chancery documents or summaries were created along with books of instructions for running the state and its economy; they contain decrees and court verdicts that date back to the midfifteenth century. Metrica volumes used by scribes were kept by the chancellor (and after the Union of Lublin in 1569 also by the sub-chancellor - these were called the 'small chancery books') and scribes. The chancellor and treasurer looked after the safety of books that were not in use as well as those which contained the most important charters. ${ }^{4}$ This is just one hint that before the early sixteenth century the Grand Duchy's archives were housed in Trakai (and if so this may have been a tradition introduced by Grand Duke Vytautas). At the beginning of the sixteenth century the Metrica were already in the Treasury in the grand-ducal palace in Vilnius. ${ }^{5}$ Care for the Metrica and other especially important state documents was similar to that prevalent in Poland. The charters and other important documents that were stored in the royal palace in Cracow were damaged by damp because they were kept in unventilated premises which officials visited may be three times a century. ${ }^{6}$ At

2 I. Sułkowska-Kurasiowa, 'Metryka Litewska - charakterystyka i dzieje', Archeion 65 (1977), p. 92 where the author cites Švitrigaila's instruction to record a commission resolution from May 211431 in the ruler's register.

${ }^{3}$ E. Banionis, ' $\mathrm{K}$ voprosu o genezise knig Litovskoi Metriki (posledniaia chetvert' XV v.', Lietuvos Metrika: 1988 metu tyrinejimai (Vilnius, 1992), pp. 20, 23-5.

${ }^{4}$ Akta Unji Polski z Litwa, ed. S. Kutrzeba and W. Semkowicz (Cracow, 1932), p. xvii. Territorial charters were kept in the Treasury but in a separate place under the chancellor's control, see: J. Jakubowski [I. Iakubovskii], 'Zemskie privilei Velikogo Kniazhestva Litovskogo', Zhurnal ministerstva narodnogo prosveshchenia 346 (March 1903), p. 241; idem, 'Archiwum państwowe W. X. Litewskiego i jego losy', Archeion 9 (1931), pp. 3-5.

5 All those who say that the grand-ducal archive was in Trakai base themselves on S. Ptaszycki [S. L. Ptashitskii], Opisanie knig i aktov Litovskoi Metriki (St Petersburg, 1887), pp. 4-5; E. Baniionis called for this matter to be cleared up in his introduction to Lietuvos metrika (1427-1506), knyga Nr. 5, ed. E. Banionis (Vilnius, 1993), p. 35.

${ }^{6}$ I. Daniłowicz pointed this out in his introduction to Kniga posol'skaia Metriki Velikogo Kniazhestva litovskogo, soderzhashchaia v sebe diplomaticheskie snoshenia Litvy v gosudarstvovanie korolia Sigismunda Avgusta s 1545 po 1572 god, ed. M. Obolenskii and I. Danilovich, I (Moscow, 1843), p. iv. 
the end of the sixteenth century it was noticed that many of the Lithuanian Metrica volumes in Vilnius were damaged and so Chancellor Leo Sapieha [Sapiega] had them copied in 1594-1607 and in 1607-1621 the Joint Sejm of the Commonwealth of the Two Nations had the copies compared with the originals. ${ }^{7}$ After this the old volumes were left in the Treasury and the new copies were handed over to the chancellor. In order to improve access to the records and protect the archive better from destruction by fire or flood, the Sejm and the grand duke decided in 1607 to locate the Metrica in private burgher houses in Vilnius. Until the first half of the eighteenth century the copied volumes and new ones were stored in several of the most comfortable and prestigious houses of Vilnius burghers in Town Hall Square, Castle [Pilies, Zamkowa] Glaziers' [Stiklių] and German [Vokiečiu] Streets. ${ }^{8}$ The Metrica was transferred to the royal archive in Warsaw in 1747-1751. ${ }^{9}$ Even before that date documents from the Grand Duchy had found their way into the archive of the Commonwealth of the Two Nations. On April 31635 Jonas Stanislovas [Jan Stanisław] Sapieha handed over to the royal archive in Warsaw material (documents and treaties) from his father Chancellor Leo Sapieha concerning relations with Muscovy. Later in 1664 they were sent to the royal archive in Cracow. ${ }^{10}$ The Lithuanian Metrica in Warsaw along with the Polish Crown Metrica formed the king's secret (that is, separate, working) archive. ${ }^{11}$ Zigmantas Kiaupa has shown how the Lithuanian gentry were dissatisfied with the increased difficulties they faced in consulting the Metrica. In dietines (among the first of which were

7 E. Banionis, 'Lietuvos Metrikos knygos: sąvoka, terminas, definicija', Lietuvos Istorijos Metraštis 1988 (1989), p. 137; G. Galenchanka, M. Spirydonau, 'Metryka Vialikaga Kniastva Litouskaga', Entsyklapedyia gistoryi Belarusi, V, (Minsk, 1999), p. 123.

${ }^{8}$ A. Baliulis, 'Iš Lietuvos Metrikos knygų ir dokumentų leidimo istorijos', Lietuvos archyvai, 7 (1996), pp. 45-47; A. Ragauskas, 'Nauji duomenys apie Vilniaus miestiečius, kurių namuose XVII a. saugota Lietuvos Metrika', Lietuvos Metrikos Naujienos, 4 (2000), pp. 24-27.

${ }^{9}$ I. Sułkowska-Kurasiowa, 'Archiwum dokumentowe Wielkiego Księstwa Litewskiego', Archiwum Główne Akt Dawnych w Warszawie / Przewodnik po zespotach [= Archiwa dawnej Rzeczpospolitej, I] (Warsaw, 1975), p. 87; P. Kennedy Grimsted, The 'Lithuanian Metrica' in Moscow and Warsaw: reconstructing the Archives of the Grand Duchy of Lithuania (Cambridge, Ma, 1984), p. 14; Baliulis, 'Iš Lietuvos', p. 47.

${ }^{10}$ Kniga posol'skaia, p. xv.

${ }^{11}$ Ibid., p. 323. 
the Trakai and Upyte Powiat Dietines) from 1786 the gentry demanded the Metrica be returned to Vilnius or Grodno. ${ }^{12}$ Algirdas Baliulis has described in detail how the Metrica books were returned to Vilnius. On 23 September 1792 the Grand Chancellor of the Grand Duchy of Lithuania, the pro-Russian Marshall of the Targowica Confederation, Aleksandras Sapieha, his deputy Juozapas Zabiela and the keeper of the great seal, Confederation Secretary Jonas Zarzyckis, issued a writ in accordance with which the Assessor's Court in Vilnius was renewed as of January 1793. The keeper of the Lithuanian, Metrica Grig Kaczanowski, was instructed to transfer the Metrica from Warsaw to Vilnius within eight weeks of the issue of this writ and to house it in the former Jesuit house next to St Casimir's Church. He was threatened with dismissal from post if he failed to comply. Transportation costs were to be covered by the Grand Duchy's Treasury, on the instruction of the Confederation Marshall. Thus at the beginning of December 1794 at least part of the Lithuanian Metrica ought to have been in Vilnius. After the Russian army occupied Vilnius following the Uprising of 1794 it was noted in the expense book of the city of Vilnius on 11 August 1794 that, after the liquidation of the state and its partition between Austria, Prussia and Russia, the Polish and Lithuanian Metrica were to be taken off as a trophy to St Petersburg. On account of this the Vilnius Magistrate's cashier spent $157 \mathrm{zl} .20$ groats on 9-18 January 1795 for a carpenter to make boxes and stud and bind them in metal and make repairs to the Metricakeeper's door. According to a receipt issued by the Imperial Senate, the latter body took charge of 834 books, 14 cardboard boxes of files and 16 bundles of separate documents. ${ }^{13}$

It happened quite frequently that state officials would not hand over to the Grand Duchy's chancery or treasury finished Metrica books, important charters and other documents. At present scholars

${ }^{12}$ Z. Kiaupa, 'The Lithuanian Metrica and the Lithuanian Nobility at the end of the eighteenth century'. Lithuanian Historical Studies, 1 (1996), pp. 81-83.

${ }^{13}$ The Lithuanian Metrica was transported to St Petersburg from both Warsaw and St Casimir's in Vilnius - R. Mielnicki, 'Archiwa Wielkiego Księstwa Litewskiego', Pamiętnik VI powszechnego zjazdu historyków polskich $w$ Wilnie 17-20 września 1935 r., I (referaty) (Lwów, 1935), p. 406; Baliulis, 'Iš Lietuvos', pp. 48-49; Kiaupa, 'Lithuanian Metrica', pp. 82-83. Professor V. Picheta, member of the USSR delegation in negotiations with Lithuania (1921) and Poland (1923) over the return of cultural relics, may have known about this in $1924-$ M. Shumeika, 'Z pratakolu pasiadzhen'iia', Spadchyna (1998), No. 6, p. 28. 
know of a considerable number of books from the fifteenth to eighteenth centuries as well as separate documents which clearly must have belonged to the Lithuanian Metrica collection and almost all of these are now in Polish archives, although a few are in Lithuania. ${ }^{14}$ In this respect the Radvila [Radziwiłł] family is a case in point. This family produced several chancellors and other high officials from the end of the fifteenth century and these kept very important state charters in their own palaces which they were in no hurry to return to the grand duke's safe keeping. This was the case too with Metrica volumes which they had drawn up. ${ }^{15}$ Chancellor Leo Sapieha informed Mikalojus Kristupas Radvila in a letter of 1594 of chancery books that had gone missing along with bundles of documents that had not been copied into the Metrica. He blamed earlier chancellors for these shortcomings. Sapieha could not find very many documents from the years when Mikalojus Radvila the Black and Radvila the Red were chancellor (1550-1565, 1566-1579). $\mathrm{He}$ also asked for chancery books and territorial charters to be returned to him. ${ }^{16}$ The Radvilas kept the originals of state documents and separate registers in Nieśwież. There is a grand-ducal charter dated 3 November 1551 granting Radvila the Black and future dukes of Nieśwież the right to store very important state charters and documents. Although that is a forgery from the first half of the eighteenth century, it provides justification for reality when, for example, during the Muscovite War of 1655-1661 the most important state papers were hidden from the Muscovite occupying force in Nieśwież after having been evacuated from Vilnius. ${ }^{17}$ Meanwhile the old books were lost during this period. The copies that had been hidden away in Prussia were returned later. ${ }^{18}$

${ }^{14}$ Most have been recorded in great detail: Kennedy Grimsted, 'Lithuanian Metrica', p. A-10-19. New documents appear from time to time: H. Lulewicz, 'Nieznana księga Metryki Litewskiej w zbiorach Archiwum Sanguszków w Krakowie', Lietuvos Metrika: 1991-1996 metu tyrinejimai (Vilnius, 1998), pp. 93-101; on a voulme of the Metrica in Lithuania see A. Dubonis, 'Lietuvos Metrikos knyga Vilniuje', Lietuvos istorijos metraštis 2000 (2001), pp. 425-28.

15 Akta Unji, pp. xvii-xviii. Metrica Book 15 contains a grand-ducal instruction to the widow Elžbieta Mykolienè-Stanislovienè Kęsgailiené, dated 29 August 1528, that she have the charter for her dotalicium (in Polish: wiano) copied into the chancery Metrica within twelve weeks; at that time some Metrica books were in the care of Elžbieta, wife of the dead palatine of Vilnius and Chancellor, Mikalojus II Radvila - see Moscow, Rossiiskii Gosudarstvennyi Arkhiv Drevnikh Aktov, Fond 389 No. 15 fos 60v-61, microfilm copy in Lietuvos valstybès istorijos archivas F. 389; Jakubowski, ‘Archiwum', pp. 2-3. 
When all the Metrica books and documents ended up in St Petersburg following the Final Partition (1795) they were sorted out before May 1798 by a special commission of the Imperial Senate and Foreign Affairs Collegium. Part of the Crown Metrica was joined to the Lithuanian Metrica and the archival holding was split into two unequal halves. Diplomatic and foreign policy documents and books were transferred to the Foreign Affairs Collegium and in 1828 they were transported to the Main Foreign Affairs Archive in Moscow (Moskovskii Glavnyi Arkhiv Ministerstva Inostrannykh Del). All the rest was placed in the First Section of the Third Department of the Russian Imperial Senate where in 1835-1838 they were rearranged in twelve sections according to book- and document type. In the Senate the books were used for practical requirements of people in the annexed Polish, Lithuanian and Belorussian territories to assess the propriety of petitions to the imperial treasury from individuals in the new gubernias. Many books, bound documents and separate papers from the Crown Metrica and some parts of the Lithuanian Metrica were passed on to Prussia in 1799 because Prussia ruled part of what had been Polish and Lithuanian (Transniemen Užnemunè) territory. After the Treaty of Tilsit (1808) this material was taken to Warsaw where it remains to this day. ${ }^{19}$ At that time the Manuscript Depot of the Imperial Public Library in St Petersburg (now the Russian National Library in St Petersburg) was headed by the famous Russian collector, Petr Dubrovskii (1754-1812?). In 18061808 he selected from the archives of the Grand Duchy and the Crown important historical documents, charters and acts such as Vytautas' oaths of homage to Jogaila (1388-1389), the Treaty of Raciąż between Jogaila and the Grand Master of the Teutonic Order (22 May 1405), the truce between Švitrigaila and the Master of Livonia (1 July 1387), fifty papal bulls, 314 acts from Livonia and 36 from Lithuania, all papers referring to Cossack affairs and documents in Polish. ${ }^{20}$ Therefore

16 G. Ia. Golenchenko, 'Neizvestnyi reestr Metriki Velikogo Kniazhestva Litovskogo v sobranii P.P. Dubrovskogo', Kniga v Belorussii: knigovedenie, istochniki, bibliografia (Minsk, 1981), p. 30.

${ }^{17}$ Akta Unji, pp. xviii-xxiii.

18 Jakubowski, 'Archiwum', p. 5.

19 Banionis, Lietuvos metrika (1427-1506), pp. 29-30.

${ }^{20}$ M. I. Avtokratova, A. S. Svetenko, 'K voprosu ob istorii formirovania i arkhivnogo osvoenia fonda LM', Issledovaia po istorii Litovskoi Metriki, I (Moscow, 1989), p. 110; Kniga posol'skaia, xix, pp. 461-67; I. Daniłowicz, Skarbiec diplomatów papieskich, cesarskich, królewskich, ksiażęcych .... I (Vilnius, 1860), Nos. 503, 504, 516, 545, 546, 550, 552, 554, 555, 561, 566, 567, 611, 791. 
the Dubrovskii and other holdings in this library still have important material concerning Lithuania and Poland such as the manuscript statutes of the Lithuanian Tribunal (1581), a fragment of the 1528 Lithuanian Muster List, documents from Vilnius and Minsk, texts dealing with the Polish-Lithuanian Union and so forth. ${ }^{21}$ Some documents came to this holding from the Radvila Archive.

The Lithuanian Metrica, the ancient state archive, was torn up barbarously and parts of it were scattered in several cities and archives throughout the Empire. Russia became and remains an empire of historical archives.

From the second half of the nineteenth century the practical importance of the Lithuanian Metrica in St Petersburg began to decline but its scholarly importance increased. Some of the diplomatic volumes of the Metrica had been in Moscow since 1828. The director of the Justice Ministry Archive, N.V. Kalachev, proposed at the end of the 1870 s joining the separate parts of the Lithuanian Metrica up in a single collection. ${ }^{22}$ After the departments within the Senate were abolished in 1887 the Metrica was sent from St Petersburg to Moscow. The Moskovskii Arkhiv Ministerstva Iustitsii took possession of 1,048 books, 393 acts, 50 genealogical tables and 19 maps. During the decade 1888-1898 several dozen books from the Crown Metrica were sent to the Main Archive of Ancient Acts in Warsaw, thereby separating them from the Lithuanian Metrica and almost all the single Lithuanian Metrica documents were handed over to the Moscow Main Foreign Affairs Ministry Archive, or rather, to its subordinate, the former state repository of ancient charters, manuscripts and seals, known today as the Oruzheinaia Palata [Armoury Chamber]. ${ }^{23}$ For some uncertain

${ }^{21}$ T. N. Kopreeva, 'Obzor pol'skikh rukopisei Gosudarstvennoi Publichnoi Biblioteki (Sobranie P.P. Dubrovskogo)', Trudy Gosudarstvennoi Publichnoi Biblioteki imeni M. E. Saltykova-Shchedrina, 8 (1958), pp. 137-65; M. M. Krom, 'Radzivillovskie akty v fondakh Rossiiskoi Natsional'noi Biblioteki: perspektivy izuchenia i publikatsii', Lietuvos Metrika: 1991-1996 metu tyrinejimai (Vilnius, 1998), pp. 229-34.

22 L. I. Shokhin, Moskovskii arkhiv Ministerstva iustitsii i russkaia istoricheskaia nauka: arkhivisty $i$ istoriki vo vtoroi polovine XIX - nachale XX veka (Moscow, 1999), p. 273.

${ }^{23}$ Avtokratova and Svetenko, 'K voprosu', pp. 112-13. The hand-over description made during the transfer of the Lithuanian and Crown Metrica was based on Ptaszycki's 1887 description of the Metrica - Lietuvos metrika (1427-1506), p. 30 [Banionis' introduction]. All the separate acts in the Oruzheinaia Palata were handed over to Poland in 1923. See also Shokhin, Moskovskii arkhiv, pp. 125, 274-75. 
reason Book 16 of the Lithuanian Metrica had found its way into the Library of the Russian General Staff. ${ }^{24}$ On the basis of the Point Four of Article Eleven of the Treaty of Riga (1921) between Russia and Poland 419 books of the Lithuanian Metrica Holding were transferred to Warsaw. ${ }^{25}$ This represented almost half of the holding because in Moscow now there are over 600 items from the Lithuanian Metrica. Although most of the volumes transferred to Warsaw were from the Polish Crown Metrica, a few volumes relating to Lithuanian affairs found their way among them. In the end the archival transformations brought about after the Bolshevik revolution meant that the Lithuanian Metrica volumes contained in the Justice and Foreign Ministry archives ended up under the same roof: in 1954 the diplomatic books of the Grand Duchy of Lithuania and everything else were joined together to form Holding [Fond] 389 which to this day is held in the Russian State Archive of Ancient Acts in Moscow [Rossiiskii Gosudarstvennyi Arkhiv Drevnikh Aktov].

After the peace treaty with Soviet Russia of July 1920 the government of the re-establishing Lithuanian state regained certain cultural treasures and collections of historical documents that had been taken away from Lithuania, but the Metrica was not among these, even though there were attempts to recover it. During negotiations in 1921 the scholarly counter-arguments of Vladimir Picheta and Sergei Shabinago (with the assistance of Matvei Liubavskii) attempted to show that the Metrica could not be returned to Lithuania because: [a] only ten percent of the contents were Lithuanian material; [b] Moscow was already an old centre for research and publication of Metrica material; [c] there was no one in Lithuania who could work on this material. This at least is what a Russian scholar told the Lithuanian delegation. $^{26}$ As the expert Paulius Galaune recalls, he was too young and lacked the knowledge and experience necessary to defend the Lithuanian stance over the return of the Metrica. In his overly severe opinion, the Lithuanian government did not give the delegation the necessary political support and more experienced experts. ${ }^{27}$ The

${ }^{24}$ Professor Bruckus' information cited in P. Galaunė, 'Lietuvos kultūros turtų likimas', Mūsu žinynas: karo mokslo ir istorijos žurnalas, 4 (1923), p. 99. This refers to the Metrica inventories drawn up in 1747-1750 which were given to Poland in 1930 - Sułkowska-Kurasiowa, 'Metryka', p. 95.

${ }^{25}$ Lietuvos metrika (1427-1506), p. 32.

${ }^{26}$ Galaunè, 'Lietuvos kultūros', pp. 88-89, 95-96.

${ }^{27}$ Ibid., pp. 91-2. Lawyers employed by the Lithuanian Foreign Affairs Ministry, S. Bieliackinas, V. Bojevas and J. Zabielskis defended Lithuania's right to obtain the return of the Metrica on strong legal grounds on 1 July 1921 - ibid, pp. 92-94. 
Lithuanian negotiators were supported by Jewish historians and public figures such as Shimon Dubnov, Julius Bruckus and Benzion Katz with the advice of the chief negotiator, S. Goldberg. ${ }^{28}$ After the meeting of the Lithuanian and Soviet Russian delegations to discuss the issue of the return of cultural treasures on August 18 1921, Paulius Galaune heard the unofficial opinion of the Russian negotiators Liubavskii and Picheta. Both declared unanimously that

the Lithuanian Metrica, Vilnius University Archive and other material would really have been handed back if the Lithuanian Republic had had control of Vilnius as its capital. They did not want cultural treasures to fall into Polish hands ... sooner or later the Metrica would be in Vilnius. It could not be otherwise and such is our hope. ${ }^{29}$

Lithuanian-Russian negotiations were observed in 1921 by secret policemen from Moscow. ${ }^{30}$ Later during the First Belorussian SSR Conference of Archivists in 1924 Professor Picheta summarized that the Soviet authorities' motive for not handing over the Lithuanian Metrica to the Lithuanians was that they did not hold the Polish-occupied Vilnius District and that on the other hand the authorities were not ready to hand over certain items to the Poles because of the issue of Vilnius. The Poles also sought to obtain the Metrica. During the conference there were calls for the Metrica not to be handed over to the Poles and that all material from the Grand Duchy of Lithuania should be transferred to the Belorussian SSR. ${ }^{31}$ The Lithuanian government prepared and made especially clear demands that the Metrica be returned during negotiations of a nonaggression pact with the USSR in $1925-26 .{ }^{32}$ During talks the Soviet side did not refuse to do this and they even allowed Ignas Jonynas into the archive to check the Metrica books according to his list, but they had decided among themselves to filibuster the issue and not return the Metrica. ${ }^{33}$ The forcefulness of the Lithuanians' stance made the Soviet side move on to the defensive.

${ }^{28}$ Ibid., pp. 97-104.

${ }^{29}$ Ibid., p. 107.

${ }^{30}$ Ibid., p. 86.

31 M. Shumeika, 'Tsiazhki shliakh viartannia: namaganni belaruskaga natsyianal'naga aktyvu dzelia zvaroty u Belarus' arkhiunai spadchyny u 1920-ia gg.', Spadchyna 1998:6, pp. 13, 15-16.

${ }^{32}$ A. Kasparavičius, 'Lietuvos Metrikos negrążinimo istorija: intarpai Lietuvos ir SSRS diplomatinių santykių mozaikai', Naujasis Židinys-Aidai 1996:3, p. 116.

${ }^{33}$ Ibid., pp. 116-18. 
The USSR People's Commissar for Foreign Affairs obliged the relevant Belorussian structures to demand that Moscow hand the Metrica over to Minsk. The First Congress of Archaeologists and Palaeographers of the BelSSR (October 17-18, 1926) passed a resolution calling for the Metrica to be handed over to the Belorussian people. ${ }^{34}$ The bolsheviks saw no political necessity for handing over cultural treasures to Lithuania. ${ }^{35}$ This is shown by the interesting comments of Konstantinas Jablonskis on the USSR in the 1930s: after 1933 it became impossible to negotiate with the USSR on the return of the Metrica and other cultural treasures. ${ }^{36}$ In his view this was the result of the Communist government's intention to seek Lithuanian political dependence and later, incorporation. This prophetic insight came to pass. Later Soviet Lithuania no longer needed to share the fraternal archival treasures with 'fraternal Soviet nations'.

We can see from the press in neighbouring states that the present-day Lithuanian attempts to regain possession of the old archive of the Grand Duchy of Lithuania and other treasures are being watched carefully. ${ }^{37}$

Research on the Metrica, especially the search for historical documents among its volumes, began in Warsaw before 1795 and was continued in St Petersburg. ${ }^{38}$ At first scholars found it extraordinarily difficult to gain access to material in this holding. In the early nineteenth century research was done in secret, often by making use of acquaintances among those charged with looking after the Metrica. The famous Russian scholar Count Nikolai Rumiantsev managed to copy as many as three volumes' worth of various documents in 1820-1822 which, like other material from the Rumiantsev Museum were taken over in 1921-1927 by the Lenin State Public Library in Moscow. ${ }^{39}$ From 1836 the tsarist

${ }^{34}$ Ibid., p. 119. Even today Belorussian scholars do not realise how they are being manipulated by Moscow - see Shumeika, 'Tsiazhki shliakh', pp. 18-21.

${ }^{35}$ Kasparavičius, 'Lietuvos Metrikos negrąžinimo istorija', p. 124.

${ }^{36} \mathrm{~K}$. Jablonskis, 'Informacinis pranešimas apie Lietuvos istorinius archyvus SSSR', Proskyna 3 (1990), pp. 167-68.

${ }^{37}$ M. Shumeika, 'Viartanne "Litouskai Metryki": mify tsi real'nats'?', Belaruskaia minuushchyna: gistoryka-publitsystychny, iliustravany chasopis 1996:2, pp. 55-57; S. Jegelevičius, "'Lietuvos imperinès pretenzijos", arba kam tarnauja prof. Patricijos Kennedy Grimsted rašiniai', Lietuvos aidas, 26 Aug. 1993, p. 9.

${ }^{38}$ A. Katilius, 'Pervye publikatsii dokumentov LM', Litovskaia Metrika: tezisy dokladov mezhrespublikanskoi nauchnoi konferentsii (Vilnius, 1988), pp. 54-55.

${ }^{39}$ Iu. Ankhimiuk, 'Litovskaia Metrika i Rumiantsevskii kruzhok', Lietuvos Metrika: 1988, p. 112. 
authorities allowed people who obtained the relevant permission to read the Metrica under the supervision of a civil service. Around three dozen people made use of this right in St Petersburg until 1887. ${ }^{40}$ In Moscow the Metrica became one of the most widelyconsulted manuscript sources. ${ }^{41}$

For thirteen years Simonas Daukantas, one of the first members of the Lithuanian nationalist movement, worked on this source in St Petersburg. He served as assistant keeper of the Metrica in the Imperial Senate between 1837 and 1850. The tsarist regime made use of Metrica data to determine the gentry status and land ownership rights of citizens of the former Grand Duchy of Lithuania, as they did when checking up on ecclesiastical rights, and urban and other charters. The imperial authorities and later the archival administration lacked specialists of Polish and Lithuanian history and the Polish and Latin languages. ${ }^{42}$ Assistant Daukantas sought out documents required from the Metrica. Kiaupa has shown the achievements of the first Lithuanian researcher to work on the Metrica. ${ }^{43}$ At present we have 1,000 folios of copies made by Daukantas. Working in the Senate, the Lithuanian historian gathered material for Teodor Narbutt to whom he sent a couple of document collections which comprise copies from the Metrica for the most part. On occasion he also complemented Jerzy Plater's collection of Žemaitian charters and prepared it for publication (with a dedication to Plater). However, the collection was never published. Daukantas also collected charters from Lithuanian towns which ran to 243 documents for 162 large and small towns. Daukantas passed on Metrica material to Bishop Motiejus Valančius when the latter was writing his history of the Diocese of Žemaitija and thanks to the good works of S. Stanevičius Michał Baliński gained Metrica material when he was writing on the volume devoted to Lithuania in a multi-volume History of Poland. Most likely Daukantas' material was used by Antoni Muchliński in his history of the Lithuanian Tatars. After Daukantas no Lithuanian researcher had access to the Metrica.

${ }^{40}$ Ptaszycki, Opisanie knig, pp. 65-74.

${ }^{41}$ L. I. Shokhin, Moskovskii arkhiv, pp. 275-76.

${ }^{42}$ Ibid., pp. 273-4, 276.

43 Z. Kiaupa, 'Lietuvos Metrikos medžiaga Simono Daukanto palikime', Mokslas ir gyvenimas 1989:11, pp. 26-27; idem, 'Trudy Simonasa Daukantasa po Litovskoi Metrike', Lietuvos Metrika: 1988, pp. 130-41; idem, 'Simono Daukanto parengti Lietuvos Metrikos medžiagos rinkimai', Lietuvos atgimimo istorijos studijos, V (1993), pp. 104-17. 
Daukantas also compiled a description of documents from the Metrica for use within the archive in $1839 .{ }^{44}$ On the other hand at the turn of the nineteenth and twentieth centuries series of documents for the history of 'Lithuanian Rus' were being published in St Petersburg, Moscow, Kiev, Warsaw and Vilnius. These contained a considerable amount of material from the Metrica. According to Vladimir Pashuto these volumes contain around 1,200 documents. ${ }^{45}$

Following the Soviet annexation and occupation in 1940/1944 Lithuanian historical studies revived during the Khrushchev 'thaw' and Jablonskis was one of the first Lithuanians to go to Moscow to consult the Metrica. His efforts led to more than 100 Metrica volumes being copied onto microfilm. These are now in the Lithuanian Institute of History in Vilnius. Later negative microfilms were made of all the books through the efforts of Domas Butenas and Sigitas Jegelevičius and deposited in the Lithuanian State Historical Archive between 1967 and 1983. ${ }^{46}$ The question of publishing archival material from the Metrica was revived in Moscow by Pashuto in 1978-1980. ${ }^{47}$ This was supposed to be the logical continuation of the work of the Russian Imperial Palaeographical Commission. In December 1980 an agreement was signed by the Academies of Science of the People's Republic of Poland and the USSR on recommencing publication of the Metrica aiming to produce two books each in 1981-1985. ${ }^{48}$ A few years later the Lithuanian Institute of History joined this project. An international editorial board was set up and this plan encouraged certain Lithuanian historians to spend some of their time on researching the Metrica.

Egidijus Banionis (1948-1993) devoted his whole attention to the Metrica and he remains the Lithuanian who has worked most

${ }^{44}$ K. Grimsted, 'The Lithuanian Metrica', p. A -33.

${ }^{45}$ V. Pashuto, 'Izdanie Litovskoi Metriki - otechestvennaia zadacha sovetskikh i pol'skikh istorikov', Issledovania po istorii, p. 8.

46 S. Jegelevičius, 'Lietuvos Metrika: kada ir kaip i Lietuvą pateko jos mikrofilmai’, Naujasis židinys-Aidai 1999:4, pp. 174-85.

${ }^{47}$ A. L. Khoroshkevich, 'Poslednie publikatorskie nachinania V. T. Pashuto i ikh sud'ba', Vostochnaia Evropa v istoricheskoi restrospektive: $k$ 80-letiu V. T. Pashuto (Moscow, 1999), p. 295.

${ }^{48}$ A. L. Khoroshkevich, 'K istorii izdania i izuchenia Litovskoi Metriki', Acta Baltico-Slavica, 8 (1973), pp. 69-94; V. T. Pashuto, A. L. Khoroshkevich, 'Sovmestnaia publikatsia sovetskikh i pol'skikh istorikov', Voprosy istorii 1981:2, pp. 158-60; M. Bychkova, 'Litovskaia Metrika - sovmestnoe izdanie sovetskikh i pol'skikh istorikov', Istoria SSSR 1981:4, pp. 214-15; T. Wasilewski, 'Polsko-radzieckie prace nad wydaniem Metryki Litewskiej’, Kwartalnik Historyczny 88 (1981), pp. 1169-71. 
intensively in this area. He initiated two conferences in Vilnius in 1988 and 1991 to discuss issues involving the Metrica. These were attended not only by Lithuanians but also by specialists from Belorussia, Ukraine and Russia. In addition Banionis published several articles on relevant Metrica issues: about the concept, terminology and definition of the 'Lithuanian Metrica', the origin of Metrica volumes in the fifteenth century and about the formation of the embassy books in 1480-1486. ${ }^{49}$ Of particular relevance is his polemic concerning principles with the US scholar and Metrica expert Patricia Kennedy Grimsted over Moscow Holding 389. On the basis of conclusions made by Polish archivists she alleges that the Lithuanian Metrica and the holding of this name do not exist as such. It is, she claims, a hybrid collection 'called the Lithuanian Metrica' which does not fit archival holding requirements at all. The name 'Lithuanian Metrica' which is in use is merely a technical term, simply a misunderstanding. Complications began with Ptaszycki who described what is now Holding 389 in 1887 and gave it a misleading name. Russian archivists further complicated archival matters by giving this collection the name of 'Lithuanian Metrica' ${ }^{50}$ Professor Grimsted can be criticized for not distinguishing, when speaking of the state archives of Poland and Lithuania, any separate archive for the Grand Duchy and its ruler and that she regards Poland as the sole heir of the heritage of the Commonwealth of the Two Nations. The researcher carefully notes how the Crown Metrica and part of the Lithuanian Metrica were returned to Poland as justice triumphed in 1924, for that is where the source originated. The remainder of the archive, the Lithuanian Metrica is still in Moscow. It is rich in historical material referring to Lithuania, Belorussia, Ukraine and neighbouring countries. The American scholar does not recognise Lithuania's rights to its historical archive. She calls the attempts made by the Lithuanian government and scholars to justify such claims 'imperial pretensions'. 51 Banionis criticized Kennedy

49 Banionis, 'Lietuvos Metrikos knygos', pp. 135-48; idem, 'K voprosu o genezise Posol'skikh knig (1480-1486)', Issledovania po istorii, I, pp. 64-84; idem, 'K voprosu o genezise knig', pp. 8-45.

${ }^{50}$ Kennedy Grimsted, 'The Lithuanian Metrica', pp. 6-7, 23-24, 30-31; eadem, 'Proiskhozhdenie dokumentov ili ikh otnoshenie k istorii Rossii (SSSR)', Otechestvennye arkhivy 1993:1, pp. 21-22. The same view that the Metrica is an archival collection is held by A. L. Khoroshkevich, 'Poslednie publikatorskie nachinania', p. 295; eadem, 'Litovskaia Metrika, sostav i puti formirovania', Issledovania po istorii, I, p. 24.

${ }^{51}$ Jegelevičius, "Lietuvos imperinès pretenzijos", p. 9. 
Grimsted for narrowing the understanding of the Metrica holding down from a definition to being an historical term of some kind. Under such circumstances only a small part of the Holding, such as the books of inscriptions, could still be termed 'Metrica', while the rest such as the court records, the Volyn' records and the social affairs records would be outside the 'Metrica'. Banionis denied that 'Metrica' is a 'term' and showed that it is a broader 'definition' and that it means the records of the ruler of the Grand Duchy of Lithuania and documents that were carried off by the Russians at the end of the eighteenth century and subsequently were formed into an archival holding (Fond 389).

The general initiative of the academies of science of the USSR and Poland to publish the Metrica books collapsed. The USSR did not publish a single Metrica book before it collapsed as a state, and Poland published only two. ${ }^{52}$ Krzysztof Pietkiewicz (University of Poznań) prepared Inscriptions Book Nine for publication in Lithuania. The publishing centre for the Lithuanian Metrica has now moved to Vilnius. ${ }^{53}$ Seventeen books have been published in Lithuania so far. ${ }^{54}$ Metrica books are being edited in the Lithuanian

${ }^{52}$ Metryka Litewska: ksiega sigillat 1709-1719, ed. A. Rachuba (Warsaw, 1987); Metryka Litewska: księga wpisów Nr. 131 (1656-1662), ed. A. Rachuba (Warsaw, 2001). This series also contains three books which do not belong to the Lithuanian Metrica as such: Metryka Litewska: rejestry podymnego Wielkiego Księstwa Litewskiego / województwo wileńskie 1690 r., ed. A. Rachuba (Warsaw, 1989); Metryka Litewska: rejestry podymnego Wielkiego Księstwa Litewskiego / województwo brzeskie litewskie 1667-1690, ed. A. Rachuba (Warsaw, 2000); Metryka Litewska: rejestry podymnego Wielkiego Księstwa Litewskiego / województwo trockie 1690 r., ed. H. Lulewicz (Warsaw, 2000). For further details see Z. Kiaupa, 'Publikatsii opisei podymnogo Velikogo Kniazhestva Litovskogo', Novosti Litovskoi Metriki, 4 (2000), p. 17.

53 A. Dubonis, 'Naivazhneishyia pratsy dasledchykau Litvy na Litouskai Metrytsy: bibliagrafia', Metriciana, 1 (Minsk, 2001), pp. 152-56.

${ }^{54}$ Lietuvos Metrika: knyga Nr. 1 (1380-1584) / Užrašymu knyga 1, Litovskaia Metrika: Kniga zapisei 1, ed. A. Baliulis, R. Firkovičius (Vilnius, 1998); Lietuvos Metrika: Knyga Nr. 3 (1440-1498) / Užrašymu knyga 3, Litovskaia Metrika: Kniga zapisei 3, ed. L. Anužytė, A. Baliulis (Vilnius, 1998); Lietuvos Metrika: knyga Nr. 5 (1427-1506) / Užrašymu knyga 5, Litovskaia Metrika: Kniga zapisei 5, ed. E. Banionis (Vilnius, 1993); Lietuvos Metrika: Knyga Nr. 8 (1499-1514) / Užrašymu knyga 8, Litovskaia Metrika: Kniga zapisei 8, ed. A. Baliulis, R. Firkovičius, D. Antanavičius (Vilnius, 1995); Lietuvos Metrika: Knyga Nr. 10 (1440-1523) / Užrašymu knyga 10, Litovskaia Metrika: Kniga zapisei 10, ed. E. Banionis, A. Baliulis (Vilnius, 1997); Lietuvos Metrika: Knyga Nr. 11 (1518-1523) / Užrašymu knyga 11, Litovskaia Metrika: Kniga zapisei 11, ed. A. Dubonis (Vilnius, 1997); Lietuvos Metrika: Knyga Nr. 12 (1522-1529) / Užrašymu knyga 12, Litovskaia 
Institute of History and Vilnius University. Three international conferences on Metrica issues have been held in Vilnius (1988, 1991, and 1996). Material from two of these has been published. ${ }^{55}$ From 1996 the Institute of History has been issuing a periodical publication under the title Lietuvos Metrikos Naujienos / Novosti Litovskoi Metriki in Lithuanian and Russian to provide news of developments in Metrica studies and publications. Metrica volumes have begun to appear in Belorussia too. ${ }^{56}$

Metrika: Kniga zapisei 12, ed. D. Antanavičius, A. Baliulis (Vilnius, 2001); Lietuvos Metrika: Knyga Nr. 25 (1387-1546) / Užrašymu knyga 25, Litovskaia Metrika: Kniga zapisei 25, ed. D. Anatanvičius , A. Baliulis (Vilnius, 1998); Lietuvos Metrika: Knyga Nr.51 (1566-1574) / Užrašymu knyga 51, Litovskaia Metrika: Kniga zapisei 51, ed. A. Baliulis, A. Ragauskas, R. Ragauskienè (Vilnius, 2000); Lietuvos Metrika (1522-1530) /4-oji Teismu bylu knyga (XVI a. pabaigos kopija), Litovskaia Metrika: Kniga sudnykh del 4, ed. S. Lazutka, I. Valikonytè et al. (Vilnius, 1997); Lietuvos Metrika (1528-1547) /6-oji Teismu bylu knyga (XVI a. pabaigos kopijos), Litovskaia Metrika: Kniga sudnykh del 6, ed. S. Lazutka, I. Valikonyte et al. (Vilnius, 1995); Lietuvos Metrika (1533-1535) /8-oji Teismu bylu knyga (XVI a. pabaigos kopija), Litovskaia Metrika: Kniga sudnykh del 8, ed. S. Lazutka, I. Valikonyte et al. (Vilnius, 1999); Lietuvos Metrika (1542) /11-oji Teismu bylu knyga (XVI a. pabaigos kopija), Litovskaia Metrika: Kniga sudnykh del 11, ed. I. Valikonytė, S. Viskantaitė et al. (Vilnius, 2001); Lietuvos Metrika: Kniga Nr. 530 (1566-1572) / Viešuju reikalu knyga 8, Litovskaia Metrika: Kniga publichnykh del 8, ed. D. Baronas, L. Jovaiša (Vilnius, 1999); Lietuvos Metrika: Kniga Nr. 531 (1567-1569) / Viešuju reikalu knyga 9, Litovskaia Metrika: Kniga publichnykh del 9, ed. L. Anužytė, A. Baliulis (Vilnius, 2001); Lietuvos Metrika: Kniga Nr. 532 (1569-1571) / Viešuju reikalu knyga 10, Litovskaia Metrika: Kniga publichnykh del 10, ed. L. Anužytė, A. Baliulis (Vilnius, 2001); Lietuvos Metrika: Kniga Nr. 564 (1553-1567) / Viešuju reikalu knyga 7, Litovskaia Metrika: Kniga publichnykh del 7, ed. A. Baliulis (Vilnius, 1996).

${ }^{55}$ Lietuvos Metrika / Litovskaia Metrika / Lithuanian Metrica: 1988 metu tyrinejimai (Vilnius, 1992); Lietuvos Metrika / Lithuanian Metrica: 1991-1996 metu tyrinejimai (Vilnius, 1998).

${ }^{56}$ Metryka Vialikaga Kniastva Litouskaga: Kniga 28 (1522-1552) / Kniga zapisau 28 (kopiia kantsa XVI st.) / Metrika of the Grand Duchy of Lithuania (1522-1552)/ Book of Inscriptions, ed. V. Mianzhynski, U. Sviazhynski (Minsk, 2000) [= Athenaeum: Commentarii historiae et culturae, kalektsyia 'Pomniki', I]; Metryka Vialikaga Kniastva Litouskaga: Kniga 44 / Kniga zapisau 44 (15591566), ed. A. I. Grusha (Minsk, 2001). A collection of articles has also been published as Metriciana: dasledavanni i materyialy Metriki Vialikaga Kniastva Litouskaga, 1 (2001) [= Athenaeum, IV]. 
Sample Texts from the Lithuanian Metrica

\section{A Crown for a Kingdom of Lithuania}

By the end of the first quarter of the sixteenth century the Grand Duchy of Lithuania had been fighting a defensive war against the Grand Duchy of Muscovy for several decades. The Muscovite ruler claimed to have inherited rights to govern all the Orthodox lands which had been made part of the Grand Duchy of Lithuania in the thirteenth and fourteenth centuries. Bloody war alternated with brief interludes of truce and Lithuania was forced to recognize Muscovite territorial and political gains. The Muscovites plucked the fruit of international political advantage. After the collapse of Constantinople in 1453 Moscow attracted the attention of the Holy See and the Holy Roman Empire. One of the main aims was to win the Muscovites over to Catholicism in return for a crown and ensure that Muscovite armies fought in the war against the Muslim Turks rather than other Christians. However, the Muscovite ruler sought to take of advantage of western European policy aims in order to consolidate his position in Rus'. Vilnius knew best what Moscow's true aims were. 1526 was the last year of a five years' truce with Moscow which had been established in 1522. Would war or peace follow on from the end of the truce? The Ottoman sultan was busy 'digesting' the fruit of recent victories in Hungary and imperial and papal envoys made their way to Moscow. Lithuanians sought to exploit this situation to increase their country's rank: to become a kingdom and thereby hope to stall further attempts by the Polish aristocracy to incorporate the Grand Duchy into the Polish Crown.

1526 August 28 - September 23, Vilnius

Original: lost.

Copy: Lithuanian Metrica, Book of Inscriptions 7, p. 1212-1220 (fo. 611-615 in Cyrillic numerals), Moscow, Russian State Archive of Ancient Acts, F. 389; microfilm copy: Lithuanian Institute of History.

Date: Deduced from N. G. Berezhkov, 'Itinerarii velikikh kniazei litovskikh po materialam Litovskoi Metriki (1481-1530), Arkheograficheskii Ezhegodnik za 1961 god (1962), 203.

Published (with some textual confusion): Akty, otnosiashchiesia $k$ istorii Zapadnoi Rossii, sobrannye i izdannye Arkheograficheskoiu kommissieiu, II (1506-1544) (St Petersburg, 1848) No. 144, pp. 171-76; Lithuanian translation and commentary by A. Jovaišas in: Šešioliktojo amžiaus raštija [= Senoji Lietuvos literatūra, V] 
(Vilnius, 2000), pp. 65-74. Translation made here from text supplied from the manuscript by A. Dubonis.

Basic literature: L. Kolankowski, Dzieje Wielkiego Księstwa Litewskiego za Jagiellonów, I: 1377-1499 (Warsaw, 1930), pp. 359, 386; idem, Zygmunt August wielki ksiażę Litwy do roku 1548 (Lwów, 1913), pp. 15-17; M. Kużmińska, 'Olbracht Marcinowicz Gasztold', Ateneum wileńskie 13 (1927), pp. 382-83; J. Smołucha, Papiestwo a Polska $w$ latach 1484-1526. Kontakty diplomatyczne na tle zagrożenia tureckiego (Cracow, 1999), pp. 23-5, 45; P. Šležas, 'Vytauto konfliktas su Lenkija dèl karūnacijos', Vytautas Didysis (Kaunas, 1930; Vilnius, 1988), pp. 205-34; Vetera Monumenta Poloniae et Lithuaniae, ed. A. Theiner, II (Rome, 1861), Nos. 257, 418, 425, 461, 474; S. Herberstein, Zapiski o Moskovii (Moscow, 1988), pp. 224-26; Istoria vneshnei politiki Rossii: konets XV-XVII vek (Moscow, 1999), pp. 109, 121, 125-26; P. Pirling, Rossia i papskii prestol (Moscow, 1912), pp. 240-43, 303, 306-308, 316-24.

This embassy comprising Prince John the bishop of Vilnius, the lord of Trakai, the starosta of Grodno, Pan Yuriy Mikhailovich Radivilovich was sent from the Council of Lords of the Grand Duchy of Lithuania. It was sent at the time when our sovereign lord his grace [King Sigismund] was at Warsaw en route from Gdańsk.

Firstly that your grace deign at this time to write to some of their graces letting them know of the envoy ${ }^{1}$ from our holy father the pope ${ }^{2}$ who was sent from his grace [the pope] to the Muscovite to make eternal peace or a truce between your grace and your grace's Muscovite enemy. ${ }^{3}$ That papal envoy is at this time in Vilnius and has informed certain of their gracious lordships that he has been sent to the Muscovite not only to make peace with your grace but also to encourage him to submit to the Holy Roman Church. And if the Muscovite so agrees, the envoy promises him a crown.

Since it is likely that the said envoy was sent from the holy father the pope more for that matter than for making peace with your grace, so the more will he labour for that Muscovite matter than for your grace's affairs, and especially so, given that no envoys from your grace were sent there with him.

However fully the envoy wishes to work on the peace with your grace, he will surely not be able to do so sufficiently in any

${ }^{1}$ Giovanni Francesco Cito, OFM, head of embassy to Muscovy, October / 13 November $1525-1526$.

${ }^{2}$ Clement VII (1523-1534), Giulio de Medici.

${ }^{3}$ Grand Duke Vasily III (1505-1533). 
way, since he is not acquainted with the matter and the origin and cause of the lack of peace between your grace and your grace's Muscovite foe.

Furthermore, gracious king, their graces your servants and your grace's council have taken account of permitting that envoy to pass through to Moscow and most of all about the matter of a crown for your grace's Muscovite foe and they advise your grace that your grace not allow that envoy to pass so readily to your grace's foe. They would advise your grace to order him to be detained in your grace's realm until your grace happily arrives here. Then your grace would see that envoy and whether to let him go on to Moscow, then your grace, may you care to do as seems most fit to your grace with the counsel of the Council of your grace's Grand Duchy of Lithuania concerning that matter of peace between your grace and the Muscovite and the crown that is intended for him. For this affects your grace's paternal inheritance and realm and, most of all, that that enemy of your grace's might gain a more elevated honour, which is something your grace would be advised not to allow to happen easily.

As previously in the days of your grace's father of glorious memory, King-Grand Duke Casimir, ${ }^{4}$ when the holy father, Pope Silvester, ${ }^{5}$ gave his niece in marriage to the grand duke of Muscovy ${ }^{6}$ and wanted to give him a crown, but your grace's father of glorious memory, even though he did not have the same discord and enmity with the Muscovite as your grace has in these times, did not wish in any way to permit the Muscovite to be crowned and he forbade this Muscovite matter to come to pass.

Then also recently Pope Leo sent his legate, Bishop Zaccharias, to you. ${ }^{7}$ The bishop also had a similar embassy to the Muscovite

${ }^{4}$ Casimir Jagellończyk, grand duke of Lithuania 1440-1492, king of Poland, $1447-1492$.

${ }^{5}$ Scribal error for Sixtus IV (Francesco della Rovere), 1471-1484.

${ }^{6}$ In fact Pope Paul II gave the niece of the last Byzantine Emperor, Constantine XII, Sophia Palaiologe, in marriage to Grand Duke Ivan III of Moscow (14621505 ) in 1469. Rumours that the pope intended recognizing Ivan as king of all Rus' aroused the opposition of King Casimir. On 7 Feb. 1484 Pope Sixtus IV assured the Polish-Lithuanian monarch that he had no intention of so doing. Later Casimir asked Pope Innocent VIII to confirm the situation (26 July 1489).

${ }^{7}$ Pope Leo X (Giovanni di Medici), 1513-1521, sent Bishop Zaccaria Ferreri (1479-1524) with Giovanni Tedaldi to Vasily III in Moscow in Dec. 1519-Jan. 1520, but King Sigismund the Elder (1506-1548) did not permit him to pass via PolandLithuania. 
from the holy father the pope, calling on him to submit to the Holy Roman Church and promising him a crown. Then your grace took counsel with their graces your Council of the Grand Duchy of Lithuania: and your grace and their graces, of the Council did not see fit to allow such a legate to pass with such an embassy to your grace's foe.

And swiftly their graces, the lords of your grace's Council, saw that they must take time to discuss letting this envoy pass and consider the matters with which he has been charged, and may your grace give sufficient instruction and take counsel with their graces, the lords of the Council of the Grand Duchy of Lithuania.

$<\ldots>$

The articles set down below should be said before his grace king personally in secret deliberation in a private place.

Gracious king, once more the lords, your grace's servants and counsellors, our brothers, have commanded us to speak before your grace about matters concerning the embassy from the holy father the pope to the Muscovite concerning a crown. For his grace the holy father the pope is so inclined to bestow that elevation and honour on your grace's foe, the Muscovite apostate from the Holy Roman Church, who acknowledges neither the true faith of God nor respects his word and honour, like your grace and all Christian lords do, and is not so noble or worthy in the lineage of his ancestors, who never did any service to the whole of Christendom and in general were the foes and defamers of the Holy Roman Church. The Muscovite stands unjustly ... and fights against Christian blood and arouses your grace's enemy the Turk and the Perekop Tatar ${ }^{8}$ and other of your grace's neighbours [against you] and prevents your grace from defending the Holy Christian Faith from the pagans. For, if your grace were not hindered by him, your grace would always, with God's help, prove mighty against the pagan foe and the Perekop enemy and your other foes.

And if his grace the holy father the pope bestows honour on one who is unworthy of it, it would be better if his grace [the pope] paid this honour [also] to your grace's son, our lord the grand duke of Lithuania and your grace's realm of the Grand Duchy of Lithuania [in recognition of] your grace's own deeds and those of your grace's ancestors, the grand dukes of Lithuania, who led this land into the

${ }^{8}$ Khan of the Perekop Horde of Tatars. 
Christian faith and stood up against the foes of the Holy Christian Faith.

Such was your grace's grandfather of glorious memory, King Władysław, ${ }^{9}$ and your grace's uncle, Grand Duke Vytautas, ${ }^{10}$ who enjoyed the support of the holy father the pope and the Christian emperor because of the fame of the deeds of Grand Duke Vytautas and his constancy and strength against his pagan foe. Having regard to the virtue of your grace's realm of the Grand Duchy of Lithuania, the holy father the pope and the emperor sent a crown to Grand Duke Vytautas and to the realm that is your grace's patrimony, the Grand Duchy of Lithuania. But then Grand Duke Vytautas departed this world and did not live to receive his crown, which was at that time on its way. The Polish lords seized it and to this day they do not wish to hand it over and thus they do not do this honour to your grace's patrimonial realm.

Their graces the lords of the Council of the Grand Duchy of Lithuania, your grace's servants, wonder greatly that their graces their Polish brothers do not wish to do this for their Christian brothers, but are not preventing that schismatic Muscovite from obtaining such honour. Their graces did not wish to advise your grace not to let that envoy pass so easily with such an embassy for Muscovy, but they would advise your grace to consider well and take counsel with your grace's Council of the Grand Duchy of Lithuania on this matter.

Similarly their graces the lords of the Council of the Polish Crown have put this thought into the mind of the Muscovite schismatic, regardless of the interests of your grace's patrimonial realm, so that your grace's realm might thus be diminished and incorporated by them into the Crown [of Poland]. They have been working for this for a long time, wishing to attach your grace's patrimony duly as a principality of the Polish Crown.

In this case their graces our brothers, your grace's native servants [the Lithuanian lords], have commanded us to beg your grace humbly that your grace not allow the Polish lords to do this

${ }^{9}$ King Władysław II of Poland (1386-1434), Grand Duke Jogaila of Lithuania (1377-1392), later Supreme Duke (1392-1434).

${ }^{10}$ Grand Duke of Lithuania, 1392-1430, cousin of Jogaila. Sought to be crowned king in 1429-1430 in negotiations with Jogaila, Pope Martin V (14171431) and Emperor Sigismund (von Luxemburg, 1410-1437). However, the pope was opposed to such a coronation. 
to us and make them, your grace's native servants, the subjects of the Polish Crown.

In particular may your grace care to forbid this for the sake of your grace's descendants, for it would always be better and more useful for your grace's descendants while your grace's patrimonial realm has a title and rights separate from the Polish Crown. This is the case at this time with your grace's son, whom the lords of the Council of the Grand Duchy of Lithuania have taken unto themselves as their lord with good will and happiness, and they have sworn allegiance to his grace, which is something which the Polish lords have completely unwilling to do hitherto. ${ }^{11}$ But if the Grand Duchy of Lithuania were subjected to the Crown there would be no such beginning for your grace's son's happy elevation.

Moreover their graces, your grace's servants of the Council, our brothers and your grace's humble servants, beg that your grace act graciously and command the Council of your grace's Crown of Poland to return the crown which was sent to the Grand Duchy of Lithuania to his grace the grand duke, your grace's son, so that his grace can be crowned during your grace's happy reign.

For, gracious king, if your grace's patrimonial realm, the Grand Duchy of Lithuania, were to have a crown, then it could not be subjected to the Crown of Poland, for one crown may not be incorporated into another. Then the Polish lords would not thirst to diminish your grace's patrimonial realm and join it to them, but there would be fraternal equality and friendship amongst us and each would act against the other's foe.

If their graces the lords of the Polish Crown do not wish to return that crown to your grace's son and to the Grand Duchy of Lithuania, then their graces of the Council of the Grand Duchy of Lithuania, your grace's servants beg your grace that your grace deign to send to the holy father the pope and the emperor asking for a crown for your son and the Grand Duchy of Lithuania. Whatever funds are necessary to this effect, their graces of the Council will raise that money with good will and will not stint to finance this matter.

${ }^{11}$ Sigismund Augustus (1520-1572). On 4 Dec. 1522 the Lithuanian nobility swore to elect Sigismund in succession to his father Sigismund the Elder when the latter died - see Lietuvos Metrika: Knyga Nr. 11 (1518-1523)Užrašymu knyga 11, No. 144. 


\section{A will}

Ivan Bogovitinovich was a member of a boyar family that traced its origins back to the end of the fifteenth century since when it had provided several well-known state servants for the grand-ducal chancery, treasury, and diplomatic service. Ivan did not follow in their footsteps. His last will and testament reveals his personal ambitions and basic values: property amassed and enriched by personal labours, just and fair distribution of wealth, family harmony, obedience from his children and strict punishment for disobedient offspring. Ivan valued hard work over making war, the traditional gentry occupation. He devotes himself and his family to God's care but does not bequeath God his property. He reveals his tense relations with his children from his first marriage. The fifteenth-century roots of sixteenth-century boyar mentality are illustrated by this source.

1550 November 12 / 1551 May 24, Vortol.

Original: not found.

Copy: Lithuanian Metrica, Inscriptions Book 35, fos. 16v-20; Moscow, Russian State Archive of Ancient Acts, F. 389; microfilm copy in Lithuanian Institute of History, Vilnius. Text edited by A. Dubonis.

Basic Literature: A. Boniecki, Poczet rodów wielkim Księstwie Litewskim w XV i XVI wieku (Warsaw, 1887), pp. 10-12, 20-24, 138-40; Polski stownik biograficzny II (Cracow, 1936), pp. 226-27 and vol XIII (Wrocław-Cracow-Warsaw-Gdańsk, 1967-68), p. 633.

Confirmation of the letter or testament of the lord Ivan Bogovitinovich ${ }^{1}$ presented by his wife and sons, wherein he bequeathed his property to them.

Sigismund Augustus by the Grace of God King of Poland, Grand Duke of Lithuania, Rus', Prussia, Žemaitija, Mazovia and other lands.

We make it known by these our presents and what will be in the future to all whom it may concern to know.

The lady wife of our marshall Ivan Bogushevich Bogovitinovich, the lady Ganna Kopoteva, and her sons Gavril, Kiriak and Mikhail and Benedykt beat their foreheads to us and presented before us

${ }^{1}$ One of Bogush Bogovitin's three sons. His brother Bogush Mikhailovich Bogovitin was land treasurer of the Grand Duchy, the grand duke's marshal and scribe (died 1530). 
the letter of our marshall, the keeper (tenutarius) of Dovgialishi, the late lord Ivan Bogushevich Bogovitinovich, her husband <... $>$

In the name of the Father and of the Son and of the Holy Ghost, Amen.

Since nothing is more certain in this world among men than death and anything that is decided amongst men is put down for memory in writing, so I, Ivan Bogushevich Bogovitinovich, my sovereign lord's marshall, keeper of Dovgialishi, being in great illness but surely of sound and full mind write this testament.

First of all I commend myself, my wife and children to the mercy of Almighty and Gracious God. My chief property is Shumsko, ${ }^{2}$ which I received from my brother as my share when it was empty, just earth and sky; in this my property of Shumsko I built a castle with great labour and expense with deep and broad water moats, and I provided it well with gunpowder. Here I built a wooden palisade with water moats around the township and I made a good beginning for maintaining peace from the enemy and I settled it with my own people. In that property of Shumsko I built a millstream and mills with great labour and expense, which the eye and wit of man may discern and appreciate. All this I bequeath to all my sons in equal parts with all the buildings and livestock. My second patrimonial estate of Kozirady, ${ }^{3}$ which I have also improved, I gave to my first wife the Lady Vasilieva as her crinile (dowry), as my letters show in more detail, and then I assigned it to my [second] wife Ganna Kopoteva. As for the property I have acquired and bought, primarily Vortol $^{4}$ with all its villages and hamlets and a third part of the town of Dakudovo, ${ }^{5}$ I have assigned this to my wife Ganna Kopoteva as her crinile. All my estate of Vortol with all the villages and hamlets and a third part of the town of Dakudovo I bequeathe after my life and the life of my wife Ganna $^{6}$ to our sons Gavtil, Kiriak, Mikhail, and Benedykt in perpetuity as their patrimony. As for the crinile belonging my wife Ganna on that estate, she has renounced it in favour of me, her husband, so that she must not bequeath this to anyone except our four sons and she has given and donated it to them after our

\footnotetext{
${ }^{2}$ Shumsko, Shumskoe, now in Ternopol district of Ukraine.

3 Unknown estate in Volyn' (now Ukraine)

${ }^{4}$ Wortel, Vortole, place in former Brest powiat, in Belorussia.

${ }^{5}$ Lyda rayon, Belorussia

${ }^{6}$ Ivan's second wife.
} 
lives. She has given those writs into my hands and I have given them for safekeeping to my brothers-in-law, the lords Ivan and Vasily Kopot, ${ }^{7}$ until our sons, their nephews, come of age. Should any of our sons die, his share will fall to those brothers who survive him. Also the estate I bought at Dushevo ${ }^{8}$ I bequeath with all its villages in perpetuity to those my four sons Gavril, Kiriak, Mikhail, and Benedykt along with all its buildings and livestock, and this estate will be held until they come of age by my wife, their mother, to have in her power and hold. The deeds and rights for this I have given into my wife's keeping until my sons come of age. The herds on my acquired estate, which run to one hundred head, I bequeath to my wife Ganna and our above-mentioned sons. The stable horses and carriers, the working horses, domestic horses, and dreys I leave to my wife for carrying out field work and for domestic needs. To my son Gavril I leave my sabre with the silver mounting; to Kiriak I give my short sword with the silver mounting; to Mikhail the long sword with silver mounting, and to Benedykt the short sword and plate armour with the green silk surcoat along with all accoutrements and the gilt helmet. All my other weapons and helmets, shields and war equipment I share out between my four sons and this should be held in trust for them by my wife until they come of age.|l

As for my elder daughters from my first wife, namely Ganna, Fedosya and Ksena, these have done me great dishonour and disobedience and have insulted me and I saw this; being in great sickness and at God's will I would grant them an honourable dowry as is within my capabilities with clothes and all appurtenances and I found them a place to live with my wife until they marry. For this her ladyship the wife of Bogush, the sub treasurer of the district, ${ }^{9}$ and the wife of Fedor came to my house to see me in my great sickness and seeing me in such difficulty she herself wished to take those three elder daughters away to her house and would not spare any effort or expense on them and would do them all goodness. In front of me, their father, they disdained my graciousness and gifts and refused to go with the good people thither as was my will. They also disdained the honourable apartments with my wife in my house. They also disdained to reside with her grace the Lady

${ }^{7}$ Sons of Sidor Vasilievich Kopot, grand-ducal marshal and scribe.

${ }^{8}$ Estate in northern part of former Slutsk powiat (district), Belorussia.

${ }^{9}$ Fedora Andreevna Sangushkovna, wife of Bogush Mikhail Bogovitinovich, land treasurer, grand-ducal marshal and scribe. 
Bogushova, wife of the district sub-treasurer, who wished them well. They wrote a complaint in their own hand to the Slutsk boyars in Borsuki, complaining against me, their father, insulting me greatly and speaking ill of me their father, speaking ill of my virtuous and good wife, who had told me much good about them, as God is my witness. For those letters written in their own hand writing came into my hands and I saw what a bad matter it is and of great insult to me and all that I bequeathed them in my first testament, the clothes, the money and honourable appurtenances, I take it all back and indeed I have taken it back into my hands. Holy Writ says that "whosoever speaketh ill of his father and mother shall die the death'. Then I destroyed my first will and made it void, and those three elder daughters of mine will not have residence with my wife Ganna after they have acted so haughtily, but in accordance with the Statute they will live with their brothers and their brothers will give them a quarter of the patrimonial estate at Shumsko for all my five daughters to divide up and share, and each will have her dowry in money. That quarter must be paid by my sons to them in cash in accordance with the Statute.

The fifty bags $[3,000]$ of groats which I mortgaged to Lord Khodkevich ${ }^{10}$ and Zenek Kravets for a house in Brest ${ }^{11}$ I leave to my wife Ganna and her sons. Gumna in Kozirady and Vortol in Dushovo I leave to my wife Ganna. What I have in coin, house buildings and all movables, large and small, I leave all this to my wife Ganna and our four sons Gavril, Kiriak, Mikhail and Benedykt. She has to remember after my life to settle everything in the way I have told her.

As for my eldest son Stefan, whom I had from my first wife, he has caused me great sadness and dishonour and has not obeyed my instructions and he did not want to be in those places where it was my will he be and he has run around the world in levity and to my sorrow. Being on my great sickbed I wanted to see him again. I sent my servant named Shimek after him with my letter to the Sejm at Piotrków, ${ }^{12}$ commanding him at the risk of otherwise incurring my displeasure to come to me, asking him to hearken more to me his father than to anyone else, and I wanted to do him

${ }^{10}$ Member of unknown branch of Chodkiewicz / Chodkevičius family.

${ }^{11}$ Brest Litovsk, Belorussia

${ }^{12}$ Piotrków Trybunalski, Piotrków województwo, Poland; frequent gathering place of the Polish-Lithuanian Sejm. 
much good. He disdained my paternal command and sent me his letter which was not addressed with my name or title and it said: 'My present lord requires my services' and so he did not wish to come to me. So let him go to his lord and let him not be surprised at me, his father, when I take back my true, noble and own acquired property and distribute it in accordance with my last will as is written above in this my testament. I will not cut him off from his patrimonial property and that of his grandfather; of this he may have a fitting and fair share with his brothers.

I signed this my testament with my own hand. Witnesses to this testament were: lord Ivan Kopot, son of the sovereign's marshal and scribe; lord Martin Chernevskii; the sons of the Brest Judge, lord Martin Zaranko, Gleb and Levko; my ghostly father, Filip, the pop from Lomaz; present too were my two priests, Father Mikolay from Dakudovo and Father Voitekh from Gorbovo.

In confirmation of this I have affixed my seal and I asked those above-mentioned good people to affix their seals. They acted in accordance with my will and placed their seals on this my testament.

Written in Vortol in the year of the Lord's Nativity one thousand five hundred and fifty, on the twelfth day of November.

Ivan Bogushevich Bogovitinovich signed with his own hand. Filip the pop signed ...

Translated by S. C. R.

\section{Author Details}

Dr Artūras Dubonis is Head of the Department of Palaeography, Lithuanian Institute of History. His special interests are in the sources of Lithuanian history of the 15th and 16th centuries (especially the Lithuanian Metrica) and the history of Lithuanian society in the 13th-16th centuries. He has published a monograph on the state structure of mediaeval Lithuania and several scores of articles on social, economic issues and foreign policy of Lithuania.

Address: Department of Palaeography, Lietuvos istorijos institutas, Kražiu 5, LT-2001 Vilnius, Lithuania.

Email: dubonis@delfi.lt 